\title{
Application areas of phosphogypsum in production of mineral binders and composites based on them: a review of research results
}

\author{
Leonid Dvorkin ${ }^{1}$, Nataliya Lushnikova ${ }^{2}$ and Mohammed Sonebi ${ }^{3}$ \\ 1 , National University of Water and Environmental Engineering, Department of Building Products Technology and \\ Materials Science, Rivne, Ukraine \\ ${ }^{2}$ National University of Water and Environmental Engineering, Department of Architecture and Environmental Design, \\ Rivne, Ukraine \\ ${ }^{3}$ School of Natural and Built Environment, Queen's University Belfast, Belfast, Northern Ireland (UK)
}

\begin{abstract}
The increase of the consumption of gypsum products in construction industry with a limited amount of natural gypsum deposits requires alternative sources of gypsum-containing raw materials. In some countries which have fertilizers industry plants, the problem can be solved using industrial wastes, e.g. phosphorgypsum - a byproduct of fertilizers' production. Kept in dumps over decades, phosphorgypsum is subjected to the chemical changes due to washing out impurities with rain and other natural factors. However, there are observed deviations of harmful impurities in dumped PG depending on its age., Phosphorgypsum of any age requires chemical treatment to neutralize remains of phosphorus and sulfuric acids, fluorine compounds. According to our researches one of the most simple and effective method of neutralization the impurities is using limecontaining admixtures. The paper presents results of laboratory tests of phosphorgypsum as a component of clinker and non-clinker binders. There were investigated the impact of phosphorgypsum as admixture for clinker binders to substitute natural gypsum. Neutralized phosphorgypsum can be applied as mineralizing admixture in calcination of Portland cement clinker. Adding 2 to $2.5 \%$ of phosphorgypsum as setting time regulator resulted in a similar physical and mechanical properties compared to mix made with natural gypsum. Another important area of phosphorgypsum application is sulphate activatoion of low-clinker blast-furnace slag cement (clinker content is less than 19\%). According to results, the incorporation of phosphorgypsum as sulphate activator in cement has the better effect as natural gypsum. Other development has been carried out to modify the phosphorgypsum binder properties. Complex additive consisted of polycarboxylate-based superplasticizer and slaked lime permitted an increase mechanical properties of hardened phosphorgypsum binder due to significant a reduction of water consumption. Such modified binder can be used as partial or complete replacement of gypsum binder for filling cements and finishing plasters. It can substitute gypsum in non-clinker binders like supersulphated cements. There were also developed compositions of supersulphated cements based on lowalumina blast furnace slag and phosphorgypsum. Supersulphated cements were tested in normal-weight and light-weight concrete.
\end{abstract}

\section{Introduction}

Synthetic gypsum is applied as an alternative for natural gypsum raw in production of construction materials [1], in the areas of location of fertilizing plants. at insufficient level of wastes recycling and reuse. For instance, the only fertilizing plant located in Western Ukraine accumulated around $10 \mathrm{mln}$ tones of accumulated phosphorgypsum (PG) wastes - a by-product of phosphoric acid production, small part of it is offered as agricultural product. According to data of Florida Institute of Phosphate Research, for each ton of phosphoric acid produced by wet processes in fertilizing plant - approximately 4.5 tons of gypsum generates. Annual world generation of $\mathrm{PG}$ is around 100-280 Mt. [2].

At gradual exhausting of the deposits of natural gypsum [3] calcium sulphate containing waste in few decades will become a main raw source for gypsum products.

The main producers of phosphate rock and phosphate fertilizers are in the USA, the counties of former USSR, China, Africa and the Middle East [2]. The leading positions in PG recycling belong to Japan, which does not have natural gypsum deposits [4].

The main disadvantages of PG are rather energyconsuming need in removing harmful admixtures and drying. There are different types of cleaning, some of them 
are rather resources and energy-consuming [5, 6]. Due to the wet technological processes PG also requires drying.

Another issue is radioactivity of natural raw for fertilizing plants and PG $[5,6]$. Activity concentrations of the radionuclides in PG vary worldwide [7].

There are suggested different areas of PG use in the construction industry, including rather challenging areas like road construction $[8,9]$, cellular gypsum [10]. One of the most common applications for different PG binders [8] is mortars and different types of concrete [11].

\section{Aim and scope of the research}

The aim of the research was revealing the areas of PG application in production of binders and composites made with PG.

Regarding the high energy consumption $\alpha$ hemihydrate and anhydrate, there research was oriented on production of PG $\beta$-hemihydrate as one of the most lowenergy environmentally friendly binders.

There are presented the key results in testing clinker based binders with phosphogypsum as mineralizing additive and setting time regulator for Portland cements of I and II type (65-94\% of clinker, which we consider as high-clinker); $\mathrm{PG}$ as sulphate activator for low-clinker blast furnace slag cements (5-19\% of clinker) and nonclinker PG binders and supersulphated cements (Fig. 1).

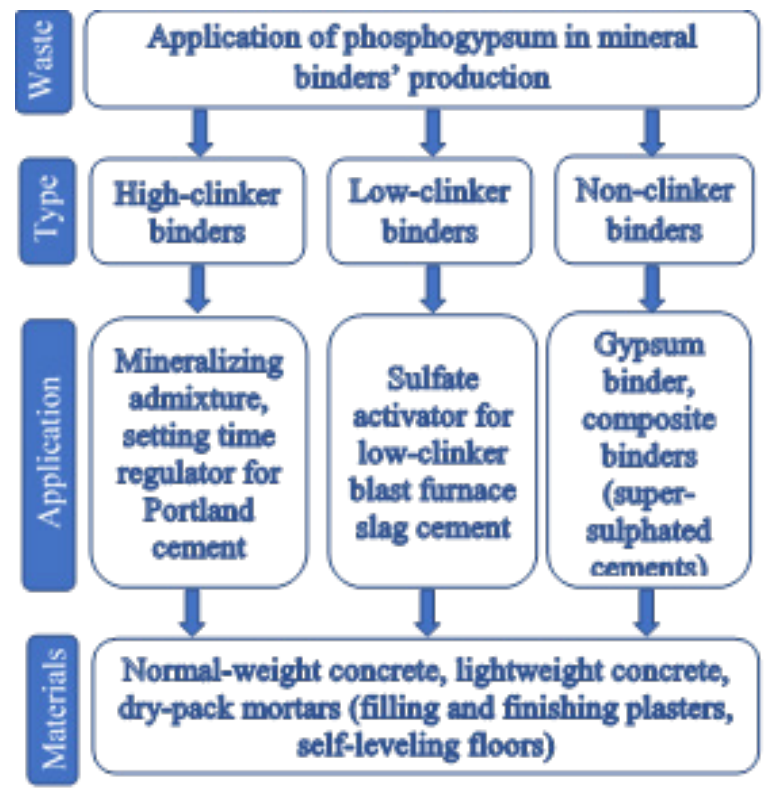

Fig.1. Research areas of phosphorgypsum application in mineral binders' production.

\section{Materials and methods applied}

Composition of phoosphogypsum (PG), blast-furnace slag (BFS), gypseous stone (GS), ordinary Portland cement (PC, I type) used in research are shown in Tab. 1.

The phosphogypum of one of the largest fertilizing plant in Western Ukraine PJSC «Rivneazot» (OstChem) was used. The Portland cement of local plants and local gypseous stone were employed.
To apply $\mathrm{PG}$ in construction materials it must be odorless and do not have toxic impurities (arsenium, cromium), harmful evaporations, minimum radioactivity [2]. As it can be seen from the Tab 1. the chemical composition of PG accumulated in dumps changes with time. Fluorine and phosphor oxides contents reduces due to washing out with rains.

Table 1. Chemical oxide composition of materials ( $\%$ by mass)

\begin{tabular}{|l|c|c|c|c|c|}
\hline $\begin{array}{c}\text { Component, } \\
\text { \% }\end{array}$ & $\begin{array}{c}\text { PG } \\
\text { fresh }\end{array}$ & $\begin{array}{c}\text { PG aged } \\
(>\mathbf{1 5} \\
\text { years) }\end{array}$ & BFS & GS & PC \\
\hline $\mathrm{SiO}_{2}$ & - & - & 39.51 & 8.54 & 22.38 \\
\hline $\mathrm{Al}_{2} \mathrm{O}_{3}$ & - & 0.34 & 6.47 & 0.70 & 5.26 \\
\hline $\mathrm{Fe}_{2} \mathrm{O}_{3}$ & - & 0.16 & 0.14 & 0.40 & 4.09 \\
\hline $\mathrm{CaO}$ & 40.0 & 38.30 & 47.19 & 29.88 & 66.25 \\
\hline $\mathrm{CaO}$ free & & - & - & - & 0.41 \\
\hline $\mathrm{MgO}$ & & 0.004 & 3.12 & 0.41 & 0.63 \\
\hline $\mathrm{SO}_{3}$ & 57.0 & 59.1 & 1.76 & 41.85 & 0.46 \\
\hline $\mathrm{MnO}$ & & - & 1.14 & - & - \\
\hline $\mathbf{P}_{2} \mathbf{O}_{5}$ total & $\mathbf{1 . 2}$ & $\mathbf{0 . 6 9}$ & - & - & - \\
\hline $\begin{array}{l}\mathbf{P}_{2} \mathbf{O}_{5} \text { water } \\
\text { soluble }\end{array}$ & $\mathbf{0 . 6}$ & $\mathbf{0 . 0 4}$ & - & - & - \\
\hline $\mathrm{R}_{2} \mathrm{O}$ & - & - & - & - & 0.29 \\
\hline $\mathbf{F}^{-}$ & $\mathbf{0 . 4}$ & $\mathbf{0 . 1 4}$ & - & - & - \\
\hline $\mathrm{Cl}{ }^{-}$ & & 0.01 & - & - & - \\
\hline L.O.I. & - & - & 0.59 & 17.87 & - \\
\hline IR & - & - & - & - & 0.21 \\
\hline
\end{tabular}

Dumped PG demonstrates multi-disparity of grains with prevalence of size ranges 0.1 to $0.4 \mathrm{~mm}, 0.05$ to 0.1 $\mathrm{mm}$ and less 0.5 almost in equal proportions [12].

According to the results of sanitary testing, radioactivity of $P G$ is within the required limits and does not exceed $370 \mathrm{~Bq} / \mathrm{kg}$ and it does not contain toxic elements [13]. Local standards determine the content of basic components of PG (see Tab. 2). As it can be seen form Tab. 1 and 2, PG meets the required standards as $\mathrm{CaSO}_{4}$ content is 96.13 to $97 \%$.

Table 2. Requirements to synthetic gypsum made of phosphogypsum [14]

\begin{tabular}{|c|c|c|c|}
\hline $\begin{array}{c}\text { Content, \% by } \\
\text { dehydrated } \\
\text { product }\end{array}$ & $\begin{array}{c}\text { Mineralizing } \\
\text { admixture }\end{array}$ & $\begin{array}{c}\text { Setting } \\
\text { time } \\
\text { regulator }\end{array}$ & $\begin{array}{c}\text { Raw for } \\
\text { gypsum } \\
\text { binder }\end{array}$ \\
\hline $\begin{array}{c}\text { CaSO} \\
\text { than } \text { more }\end{array}$ & 80 & 80 & 90 \\
\hline $\begin{array}{c}\mathrm{P}_{2} \mathrm{O}_{5} \text { (total); } \\
\text { less than }\end{array}$ & 1.8 & 1.4 & 1.5 \\
\hline $\begin{array}{c}\mathrm{P}_{2} \mathrm{O}_{5} \text { (soluble), } \\
\text { less than }\end{array}$ & 0.7 & 0.18 & 0,15 \\
\hline $\begin{array}{c}\text { F (total), less } \\
\text { than }\end{array}$ & 0.9 & 0.36 & 0.4 \\
\hline Whyh., less than & 14.5 & 14.5 & 14.5 \\
\hline
\end{tabular}


Water consumption of binders was tested according setting time Vicat needle test [15], normal consistency of cement [16]. For determination compressive and bending strength [17], prisms of binder sand mortar in 1:3 ratio 40x40x160mm were tested. Quartz sand used for preparing the PC, BFSC and supersulphated cement (SSC) based mortar specimens has the following properties: fineness modulus 1.9 to 2.0 , content of washed out admixtures about $1.7 \%$, real density $-2.69 \mathrm{~g} / \mathrm{m}^{3}$, bulk density $-1.38 \mathrm{~g} / \mathrm{m}^{3}$, voidage $-48.7 \%$. The average value for 3 specimens was determined. Basic properties were considered in comparison to those of control specimens without PG.

\section{Preparation of phosphogypsum to application in production of construction materials}

According to preliminary research there have been selected parameters of PG production stages: drying, neutralizing harmful admixtures, fineness of grinding. Applying statistical modeling method, it was determined, that temperature of thermal treatment (drying) is 150 to $160{ }^{\circ} \mathrm{C}$, percentage of the neutralizing admixture (slaked lime) 2 to $2.5 \%$ (by PG weight); PG binder was ground up to maximum sieve residue $\# 02$ up to $5 \%$ [18]. PG neutralization with lime milk was made. For complete neutralization and providing sufficient homogeneity, it was kept for 1 to 3 days (subjected to ageing). Before calcination $\mathrm{PG}$ was dried to a residual humidity - 1 to $2 \%$, drying temperature was up to $100{ }^{\circ} \mathrm{C}$. For obtaining the binder, neutralized PG was calcined during $2 \mathrm{~h}$, after that it was grounded in the laboratory ball mill.

Neutralizing with lime milk led to increase of PG moisture content by 4 to $5 \%$ and required additional drying of the material. For practical technology, dry methods for PG neutralizing are the most interesting, using powders of slaked lime. At the same time, dry methods are possible when moisture content of PG is 15 to $20 \%$. At thorough mixing of $\mathrm{PG}$ with a neutralizing additive, introduced in an amount of 2 to $3 \%$ (in terms of $\mathrm{CaO}$ ), after keeping for 2 to 6 hours the $\mathrm{pH}$ value increases from 4 to 5 to 8 to 9 [13].

To give the $P G$ a marketable form and high processability it is necessary either to granulate or briquette it. The known methods of granulation are complex, require the use of bulky drying-roll-up devices (drying drums, bowl or drum granulators), in addition, they do not provide required strength of granules and their safety at transport and technological operations. To our opinion, briquetting of the material is more promising.

Table 3. Properties of phosphogypsum briquette

\begin{tabular}{|c|c|}
\hline Parameters & Value \\
\hline Diameter of briquette, $\mathrm{mm}$ & 60 \\
\hline Thickness, $\mathrm{mm}$ & $10-15$ \\
\hline Humidity, $\%$ & $7-12$ \\
\hline Compacting pressure, $\mathrm{MPa}$ & $20-40$ \\
\hline Compressive strength, $\mathrm{MPa}$ & $6-10$ \\
\hline
\end{tabular}

Briquetting of neutralized PG was worked out to prevent dusting, improve transportation conditions, dosage and storage. The experiments were carried out on a briquette-roll press. After laboratory tests, industrial approbation was carried out. The optimal pressing parameters, at which the compressive strength of the briquette was from 6 to $10 \mathrm{MPa}$, correspond to the moisture content of the material 7 to $12 \%$, pressure 20 to $40 \mathrm{MPa}$. To prepare a mass containing PG and lime to it is necessary to dry the dump PG. The characteristics of a briquette of industrial production are given in Table 3 .

\section{PG as admixture for Portland cement}

\subsection{Phosphogypsum as mineralizing admixture}

The use of PG as mineralizer at Portland cement clinker calcination is known in many countries (Japan, Russia, Lithuania and others). Adding 2 to $3 \%$ of $\mathrm{PG}\left(1 \%\right.$ of $\left.\mathrm{SO}_{3}\right)$ allows to reduce fuel consumption by $1 \%$ and improve grindability of cement [13].

The reason for adding of mineralizing admixture in local plant was caused by lime saturation factor of the PC sludge and presence of coarse-grained silica in charge mixture.

There have been determined the amount of bound $\mathrm{CaO}$ depending on the type and dosage of additives (blast furnace slag and PG) (Tab. 4) and the temperature of calcination (Fig. 2). As follows from the data obtained, at calcination in a laboratory furnace during $10 \mathrm{~min}$, the introduction of PG in an amount up to $1 \% \mathrm{SO}_{3}$ allows to accelerate the binding of free lime both without slag and with slag. At a temperature of $1400^{\circ} \mathrm{C}$, almost complete lime binding was observed (Tab. 4, Fig. 2). PC clinker used has lime saturation factor $\mathrm{LSF}=0.93$, silica ratio $(\mathrm{SR})=2.4$; alumina ratio $\mathrm{AR}=1.3$.

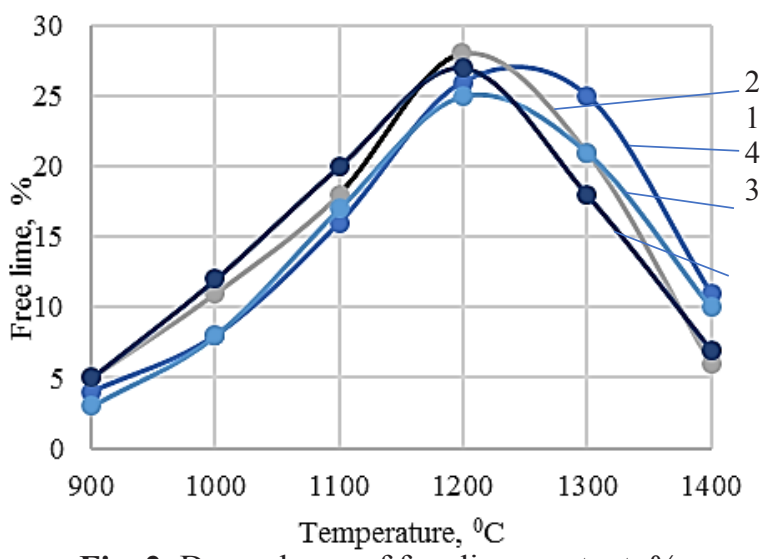

Fig. 2. Dependence of free lime content, $\%$ depending on the temperature of calcination

Table 4. Proportion of sludge, $\%$

\begin{tabular}{|c|c|c|c|}
\hline$\#$ & Dry sludge & BFS & PG (SO 3 ) \\
\hline 1 & 100 & 0 & 0 \\
\hline 2 & 98 & 0 & $2(1)$ \\
\hline 3 & 96 & 4 & 0 \\
\hline 4 & 94 & 4 & $2(1)$ \\
\hline
\end{tabular}


At temperature of calcination $1400^{\circ} \mathrm{C}$ for sludge without admixture $\mathrm{CaO}$ content was $11 \%$ (\#1), at adding PG- 6\% (\#2), when slag was added these values were $10 \%$ (\#3) and 7\% (\#4).

These data demonstrate mineralizing effect of $\mathrm{PG}$, which can be applied in cement plant rotary kilns. It is rational to add $\mathrm{PG}$ into the kiln in the loose state with the slag.

\subsection{Phosphogypsum as setting time regulator}

Phosphogypsum was tested as a substitute of natural gypsum for setting time regulation of cement. Compositions, water consumption of cement paste and $\mathrm{W} / \mathrm{C}$ to provide flow spread diameter of tested cement sand mortars 110 to $116 \mathrm{~mm}$ are given in Tab.5.

As it can be seen from the results of setting time testing (Fig. 3), there is no direct dependence of setting time change and GS or PG dosage variation.

Table 5. Testing phosphogypsum as setting time regulator

\begin{tabular}{|c|c|c|c|c|c|c|}
\hline$\#$ & $\begin{array}{c}\text { PG, } \\
\text { \%SO3 }\end{array}$ & $\begin{array}{c}\text { GS, } \\
\text { \% } \\
\mathbf{S O}_{3}\end{array}$ & $\begin{array}{c}\# 008 \\
\text { sieve } \\
\text { residue }\end{array}$ & $\begin{array}{c}\text { Water } \\
\text { demand, } \\
\text { \% }\end{array}$ & W/C & $\begin{array}{c}\text { Flow } \\
\text { spread, } \\
\text { mm }\end{array}$ \\
\hline 1 & - & 3 & 10 & 27,0 & 0.40 & 115 \\
\hline 2 & 1.5 & - & 9 & 27,5 & 0.40 & 115 \\
\hline 3 & 2.5 & - & 10 & 27,2 & 0.40 & 115 \\
\hline 4 & 0.5 & 2.5 & 8,6 & 26,0 & 0.42 & 110 \\
\hline 5 & 1.5 & 1.5 & 8,7 & 26,5 & 0.43 & 111 \\
\hline 6 & 2 & 1 & 9,2 & 27,0 & 0.40 & 110 \\
\hline
\end{tabular}

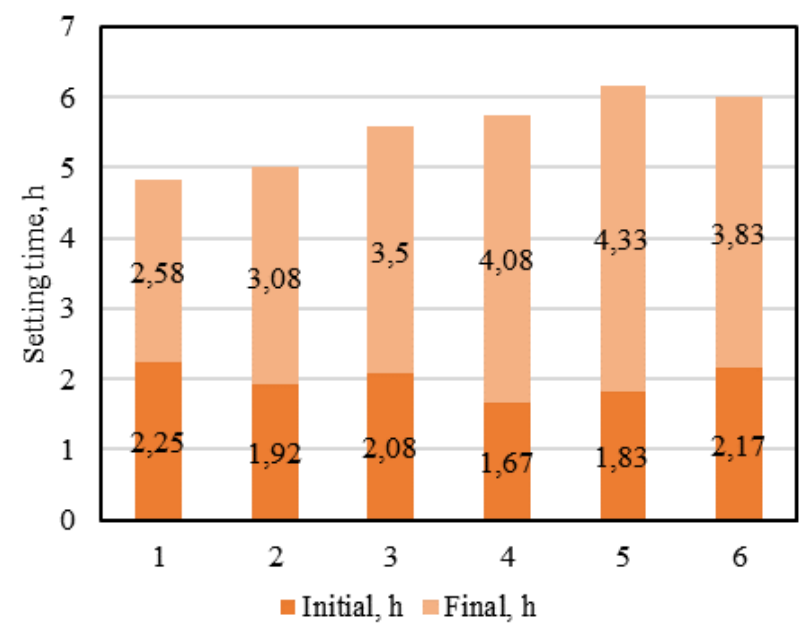

Fig. 3. Setting time of $P C$ with $P G$ and GS as regulators

Fig. 4 and Fig. 5 present kinetics of bending and compressive strength of cement mortar. As it can be seen the compressive strength of cement with PG additive is compatible to that with natural gypsum and meets the requirements of the standards for CEM I $42.5 \mathrm{R}$. Therefore, $\mathrm{PG}$ can replace natural gypseous stone. The optimum dosage of $\mathrm{PG}$ is from 2 to $2.5 \% \mathrm{SO}_{3}$.

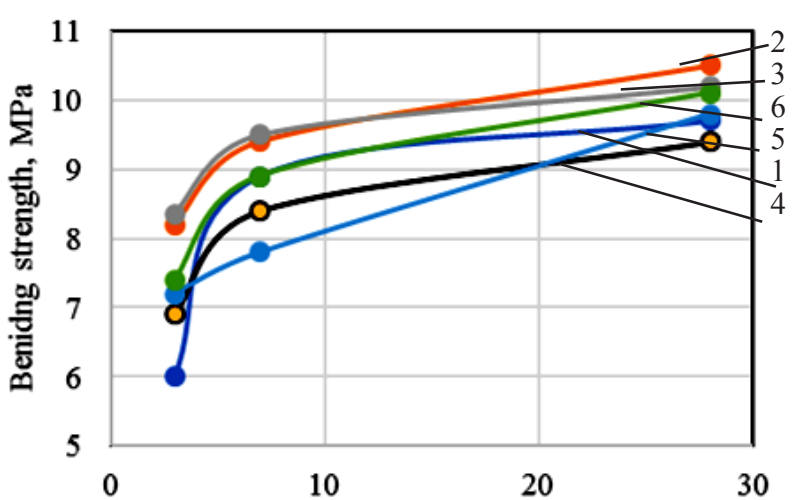

Age of hardening, days

Fig, 4. Kinetics of bending strength of the cement mortar depending on the type and dosage of setting time regulator (\# of compositions according to Tab. 5)

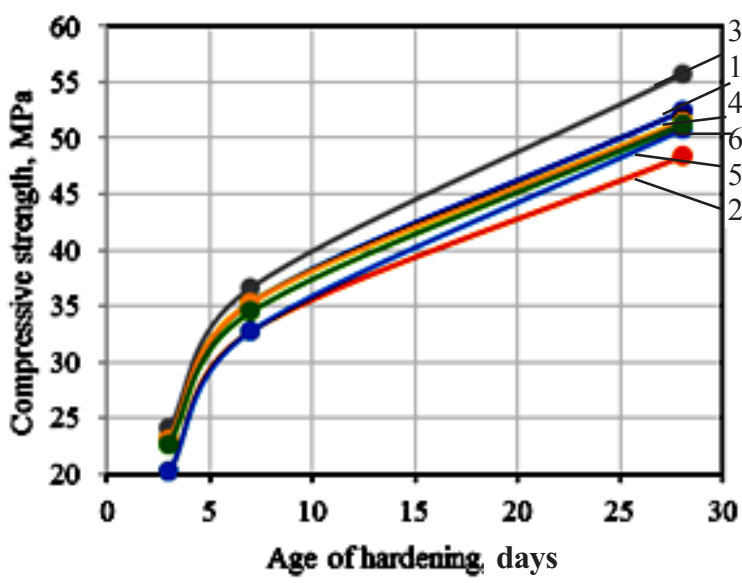

Fig, 5. Kinetics of compressive strength of the cement mortar depending on the type and dosage of setting time regulator (\# of compositions according to Tab. 5)

\section{PG as sulphate activator to low-clicker binders}

Sulphate activation of low-clinker binders can be made by different modifications of calcium sulphate: calcium sulphate dihydrate (gypseous stone and PG), calcium sulphate hemihydrate and anhydrite.

There was applied aged PG (stored more than 1 year in the dump) and gypseous stone for comparison setting time and strength parameters of low-clinker binder - BFSC. The content of sulphate component varied from 3.5 to $5.5 \% \mathrm{SO}_{3}$. Components ratio of binder: BFS $-88 \%$, clinker- $12 \%$. Specific surface area of the binder was 450 $\mathrm{m}^{2} / \mathrm{kg}$. Water consumption of the low-clinker BFSC depending on the type of sulphate component and its dosage is shown in Tab. 6 .

To reduce water consumption for all the compositions naphthalene formaldehyde superplasticizer was used (1\% by weight of binder). The research results of setting time and strength of cement mortar at the age of 28 days are shown on Figs. 6 to 8 . 
Table 6. Composition and water consumption of low-clinker BFSC

\begin{tabular}{|c|c|c|c|}
\hline$\#$ & PG, $\%$ & GS, \% & $\begin{array}{c}\text { Water demand, } \\
\mathbf{\%}\end{array}$ \\
\hline 1 & 3.5 & - & 22.7 \\
\hline 2 & 4.5 & - & 23.3 \\
\hline 3 & 5.5 & & 24.5 \\
\hline 4 & - & 3.5 & 23.5 \\
\hline 5 & - & 4.5 & 25.5 \\
\hline 6 & - & 5.5 & 26.2 \\
\hline
\end{tabular}

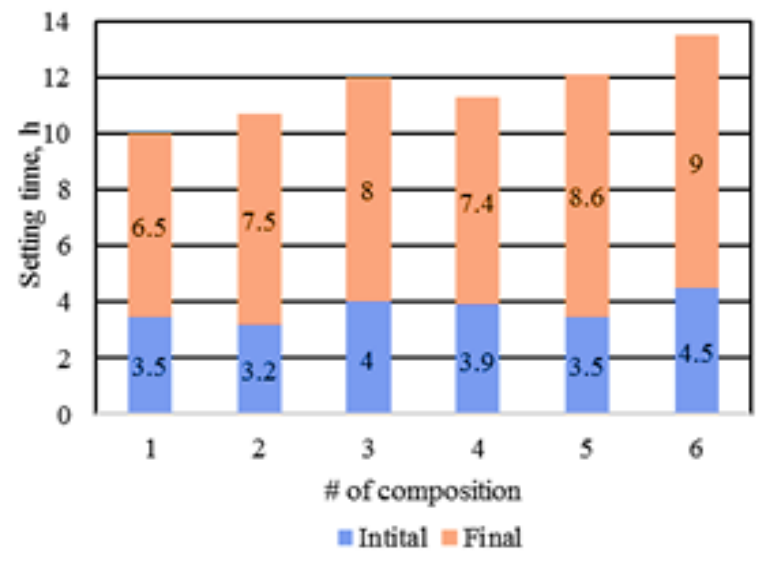

Fig. 6. Setting time of low-clinker BFSC

According to the obtained data, we can conclude that PG is more effective sulphate activator than natural gypsum. Probable reason for this are the structural features of the PG. It is characterized by porous structure, preserved even after grinding, high dispersity of PG and the presence of impurities in its composition. Fluorites, mainly fluorspar $\mathrm{CaF}_{2}$, dominate, and it is the accelerator of hardening of slag-based binders $[19,20]$. PG is also the cheapest sulphate component; its use contributes to solving environmental problems of storage and disposal of potentially hazardous industrial waste. However, it should be noted that the increase of sulphate component dosage of more than $7.5 \%$, both PG and gypseous stone, led to a

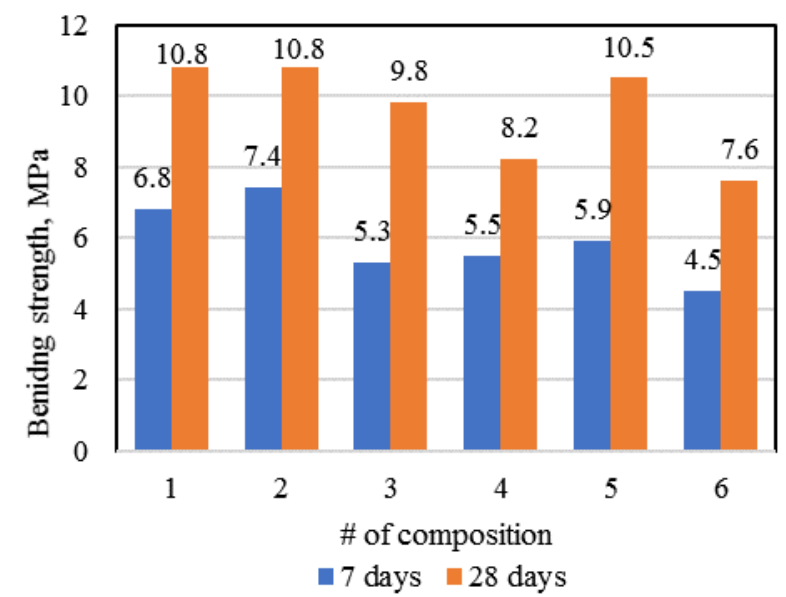

Fig. 7. Bending strength of low-clinker BFSC

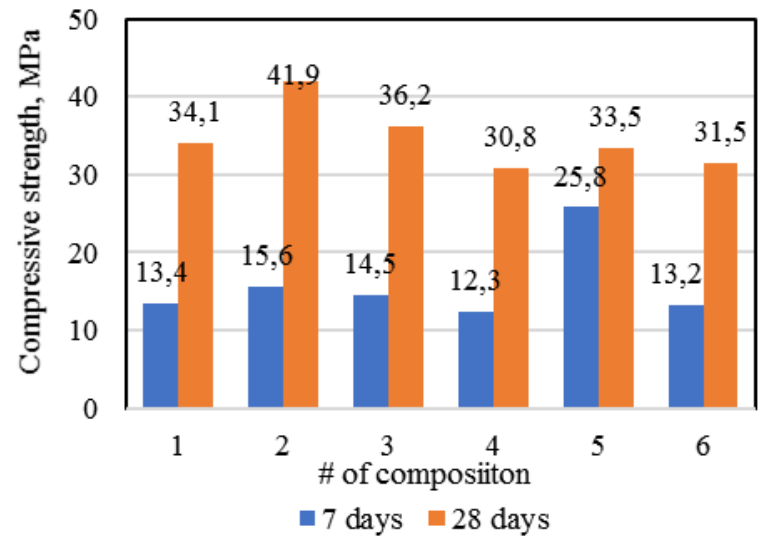

Fig. 8. Compressive strength of low-clinker BFSC

decline in the compressive strength of low-clinker BFSC [21]. The reason is that the dual activation of slag by calcium hydroxide, which is formed by hydration of clinker, and sulphate component, destructive processes are possible due to recrystallization of hydrosulphoaluminates. That led to decreasing hardening rate and compressive strength reduction. Therefore, the optimal proportion of activators should be considered. As it can be seen from Fig. 7 and 8, the optimum content of $\mathrm{PG}$ is $4.5 \%\left(\mathrm{SO}_{3}\right)$. That permits achieving maximum bending and compressive strength. Comparing to the strength of BFSC with GS, PG permits increase bending strength on 15 to $20 \%$ and compressive strength on 10 to $25 \%$.

Preliminary tests proved the possibility of application low-clinker BFSC in production of normal-weight concrete, fiber-reinforced concrete, dry pack mixes for masonry mortars [21].

\section{Modified gypsum binders}

One of the important disadvantages of phosphorgypsum is its high-water consumption, which is limens its application as substitute for calcium hemihydrate binder. Water gypsum ratio of $\mathrm{PG}$ at normal consistency by Suttard cylinder is 0.9 , comparing to gypsum paste on natural gypsum is 0.6 . That causes low strength of hardened gypsum.

Therefore, the ways of reduction water consumption with subsequent strength increasing are vital. The effective way of modifying PG binder is application of superplasticizers (SP). However, most of known highrange water reducers, produced for alkaline based binders like Portland cement, have lower effect in neutral gypsum environment [22]. Previous researches proved the effectiveness of polyacrylates like Dynamon and modified polycarboxylate ethers as Melflux.

To increase the water reducing effect slaked lime added. It provided formation of alkaline environment and both steric and electrostatic effect of molecules of modified polycarboxylate ether was more evident [22, 23]. Series of researches proved that stability of gypsum plaster under the influence of steric effect is better than that caused by electrostatic repulsive force $[12,24]$. It means 
that there is no need in using setting retarders for such binders.

Superplasticizer used and compositions of modified binders are given in Tab. 7. The dosage of SP was selected to provide minimum $\mathrm{W} / \mathrm{G}$ ratio at forced mixing the paste. Application of "forced" mixing during 2 to 3 min at adding modifier SP+lime led to achieving higher homogeneity, higher water-reducing effect and high strength parameters (Fig. 9 and 10). Small portions of binder for laboratory research have been mixed by hand for 3 to $6 \mathrm{~min}$. Consumption of lime as a part of multifunctional modifier is about $3 \%(2 \%$ of $\mathrm{CaO})$.

Table 7. Compositions of modified PG binder with different SP (flow spread of Suttard cilinder-180-220 mm)

\begin{tabular}{|c|c|c|c|c|}
\hline$\#$ & $\begin{array}{c}\text { Type of } \\
\text { SP }\end{array}$ & $\begin{array}{c}\text { SP } \\
\text { content, \% } \\
\text { by PG } \\
\text { weight }\end{array}$ & $\begin{array}{c}\text { Lime } \\
\text { content, \% } \\
\text { by PG } \\
\text { weight }\end{array}$ & W/G \\
\hline 1 & $\begin{array}{c}\text { Dynamon } \\
\text { SP3 }\end{array}$ & 0.66 & 3 & 0.34 \\
\hline 2 & $\begin{array}{c}\text { Melfulx } \\
1641 \mathrm{~F}\end{array}$ & 0.60 & 3 & 0.32 \\
\hline 3 & $\begin{array}{c}\text { Melfulx } \\
2651 \mathrm{~F}\end{array}$ & 0.60 & 3 & 0.31 \\
\hline
\end{tabular}

For complex additive Melflux $1641 \mathrm{~F}+$ lime the optimal setting time is within 18 to $25 \mathrm{~min}$, for Melflux $2651 \mathrm{~F}+$ lime -50 to $70 \mathrm{~min}$, for Dynamon SP3+lime setting time was 15 to 20 min. Modified PG binders based are slow-hardening gypsum binders.

The data in Figs. $9 \& 10$ demonstrate that mechanical properties of PG binder containing polyacrylate SP are close to the strength of specimens containing polycarboxylate SP. The effectiveness of Melflux $2651 \mathrm{~F}$ is higher than Melflux $1641 \mathrm{~F}$. It can be explained by longer side chains of the molecules; therefore, the steric effect is higher.

SEM micrographs (Fig. 11) show that morphology of $\mathrm{CaSO}_{4} \cdot 2 \mathrm{H}_{2} \mathrm{O}$ is not related to the type and portion of admixtures comparing to the PG binder specimens. However, at the application of optimal values of SP and slaked lime denser disposition of crystals is observed.

There have been conducted research on properties of plasters, filling cements, self-levering floor mortars with PG binder and PG filler. As fine aggregate quartz sand was

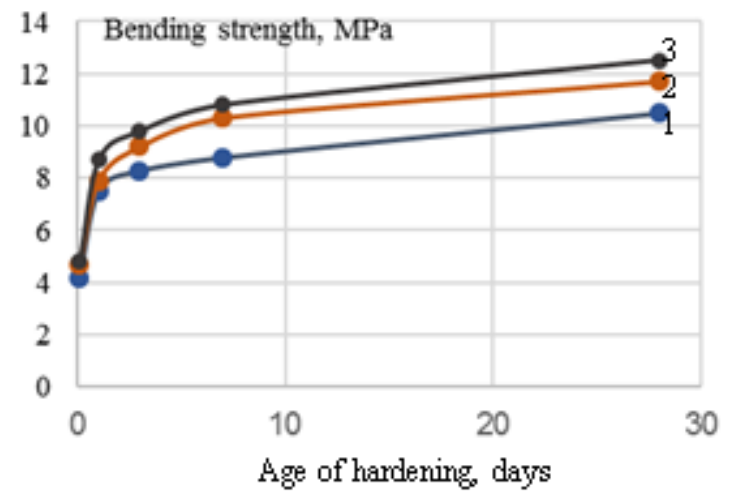

Fig. 9. Kinetics of bending strength of modified PG binder depending on the type of SF

used, water retaining admixture of Tylose and citric acid
Compressive strength, $\mathrm{MPa}$

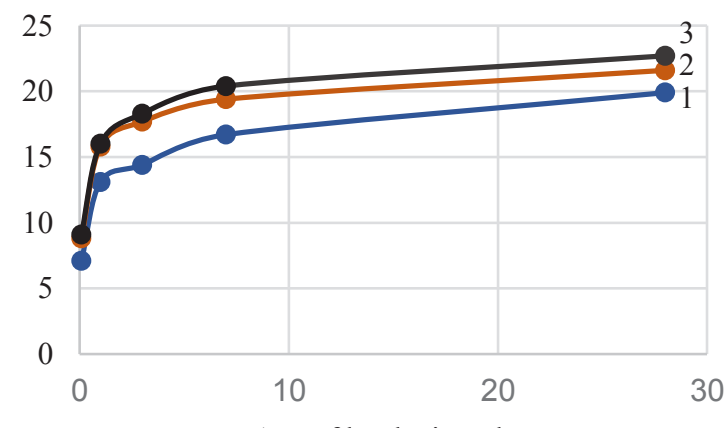

Age of hardening, days

Fig. 10. Kinetics of compressive strength of modified PG binder depending on the type of SP)
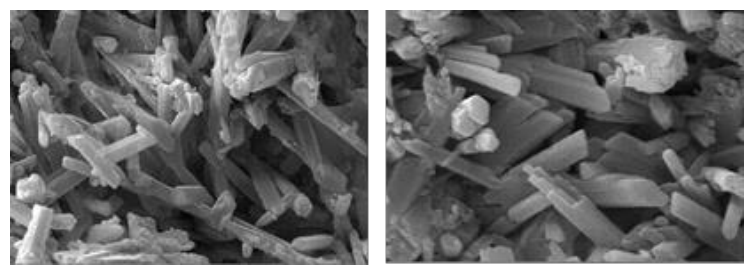

Fig 11. Micrographs of non-modified PG binder (W/G $=0.9$, left) and modified PG binder specimens $(0.6 \%$ Melflux $+3 \%$ lime, $\mathrm{W} / \mathrm{G}=0.32$, right $)$

as setting time regulator were applied [25]. Bending strength of the mortars was 1.5 to $2.5 \mathrm{MPa}$, compressive strength 2.5-6.5 $\mathrm{MPa}$.

\section{PG as a component of SSC}

Supersulphated cement (SSC) is low-energy and lowresource consuming non-clinker cement [26]. It is obtained by combined intergrinding of blast furnace slag, sulphate and alkaline activators in small relative quantity. Proportion of the binder under research selected as optimum was [12] was as follows: $85 \%$ of blast furnace slag, $10 \%$ of sulphate activator and $5 \%$ of alkaline activator (PC). Table 8 shows the components of SSC with different types of sulphate components.

Table 8. Sulphate components of SSC

\begin{tabular}{|c|c|c|c|}
\hline$\#$ & $\begin{array}{c}\text { Type of sulphate } \\
\text { component }\end{array}$ & $\mathbf{W} / \mathbf{C}$ & $\begin{array}{c}\text { Specific } \\
\text { surface of } \\
\mathbf{S S C}, \mathbf{~ m}^{2} / \mathbf{k g}\end{array}$ \\
\hline 1 & Gypseous stone & 0.4 & 610 \\
\hline 2 & $\begin{array}{c}\beta \text {-hemihydrate (building } \\
\text { gypsum0 }\end{array}$ & 0.4 & 615 \\
\hline 3 & Phosphogypsum & 0.4 & 620 \\
\hline
\end{tabular}




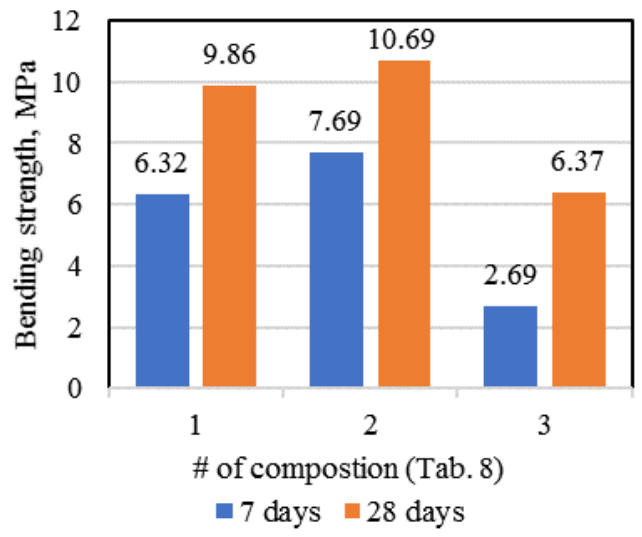

Fig. 12. Bending strength of modified SSC depending on type of sulphate component

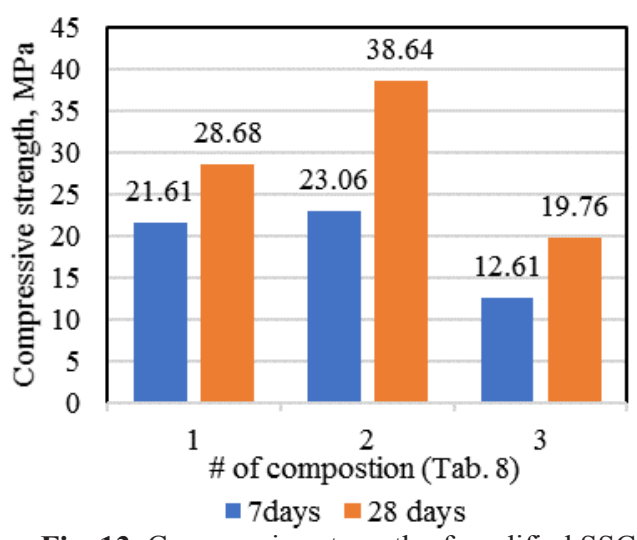

Fig. 13. Compressive strength of modified SSC depending on type of sulphate component

Table 9. SSC based on PG modified with superplasticizers

\begin{tabular}{|c|c|c|c|}
\hline$\#$ & Superplasticizer & $\begin{array}{c}\text { SP content, \% } \\
\text { SSC weight }\end{array}$ & W/C \\
\hline 1 & Melflux-2651F & 0.2 & 0.37 \\
\hline 2 & Melflux-2651F & 0.4 & 0.33 \\
\hline 3 & Melflux-2651F & 0.6 & 0.29 \\
\hline 4 & Dynamon SP3 & 0.2 & 0.38 \\
\hline 5 & Dynamon SP3 & 0.4 & 0.34 \\
\hline 6 & Dynamon SP3 & 0.6 & 0.30 \\
\hline
\end{tabular}

As it can be seen in Figs. 12 and 13, PG is the most effective sulphate component of SSC. Strength of SSC with building gypsum sulphate slag binders using plaster was as almost twice lower as with PG. It can be explained by different rate of calcium sulphate dihydrate and ettringite crystallization and formed by the interaction of aqueous plaster with water. Crystallization of $\mathrm{CaSO}_{4} \cdot 2 \mathrm{H}_{2} \mathrm{O}$ is rapid and ends no later than in 2 hours after mixing with water, while formation of ettringite lasts few days, thus destroying the crystal structure of hardened gypsum and hardened SSC structure.

For reduction of water consumption of SSC based on PG there was suggested adding SP (Tab. 9).

As it can be seen from Fig. 14 the bending strength is almost in direct proportion to SP dosage.

Superplasticizers make strong effect on water demand of $\mathrm{SSC}$, and permit to reduce $\mathrm{W} / \mathrm{C}$ from 0.4 to 0.3 at keeping the same consistency of fresh mortar. The compressive strength of the binder (Fig. 15) increased respectively from 1.2 and 1.5 times comparatively to control composition at dosage of SP $0.4 \%$.

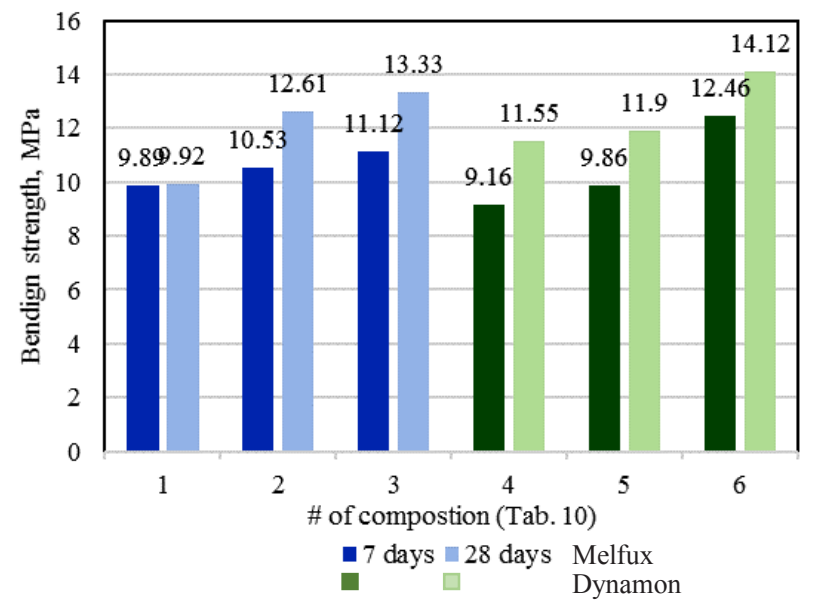

Fig. 14. Bending strength of modified SSC based mortars

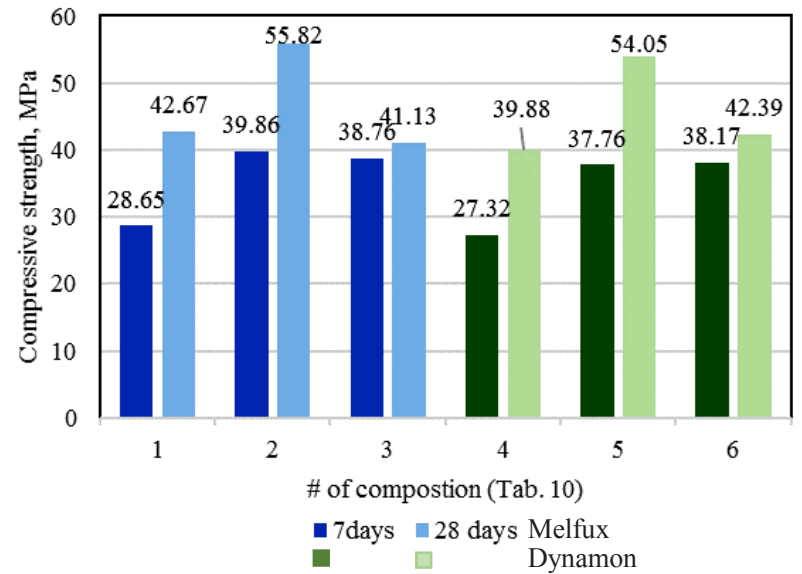

Fig. 15. Compressive strength of modified SSC based mortars

Reducing water-binder ratio to $0.29-0.3$ resulted in a reduction of strength, despite the preservation of a sufficient level of mortar workability. We can assume that water content was insufficient for completion the transfer of existing $\mathrm{CaSO}_{4} \cdot 2 \mathrm{H}_{2} \mathrm{O}$ in hydrosuphoaluuminates, in particular ettringite (Fig. 15). Therefore, the optimal content SP to maximize compressive strength was about $0.4 \%$ by weight of SSC at $\mathrm{W} / \mathrm{C}=0.3-0.34$ ).

The setting time of SSC was not affected by type of sulphate component as well as by the presence of SP. Water consumption and setting time corresponds to those for ordinary Portland cement (Tab. 10).

Table 10. Normal consistency and setting time of SSC

\begin{tabular}{|c|c|c|c|c|c|c|c|}
\hline \multirow{2}{*}{$\#$} & \multicolumn{4}{|c|}{ Components, \% } & \multirow{2}{*}{$\begin{array}{c}\text { SP, } \\
\%\end{array}$} & \multicolumn{2}{c|}{$\begin{array}{c}\text { Setting time, } \\
\text { h-min }\end{array}$} \\
\cline { 2 - 5 } \cline { 7 - 8 } & BFS & PG & PC & GS & & initial & final \\
\hline 1 & 85 & 10 & 5 & - & - & $3-10$ & $7-40$ \\
\hline 2 & 85 & 10 & - & 5 & - & $3-30$ & $7-50$ \\
\hline 3 & 85 & 10 & 5 & - & 0.2 & $4-20$ & $7-40$ \\
\hline 4 & 85 & 10 & 5 & - & 0.4 & $4-40$ & $7-10$ \\
\hline
\end{tabular}


Microstructure of SSC specimens at the age of 7 days is shown on Fig. 16.

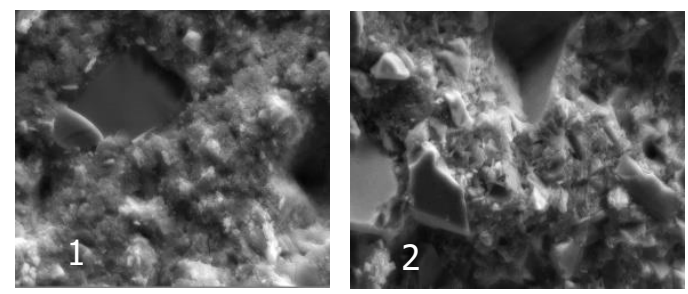

Fig. 16. Micrographs hardened SSC binder (BFS-85\%, PG$10 \%, \mathrm{PC}-5 \%$ ) : 1) W/C $=0.4$, without admixtures (left) and $\mathrm{W} / \mathrm{C}=0.33$; with $0.4 \%$ Melflux (right) $\times 1000$

Comparison of SEM images specimens of SSC demonstrate the presence of large number of needle-like prismatic crystals of ettringite and lamellar crystals of calcium sulphate dihydrate. The use of superplasticizer affected of new formations. Prismatic structures that can be attributed to the calcium sulphate dihydrate gypsum and hydrosulphoaluminate. Fibrous structures are likely to indicate the presence of significant amounts of low-basic calcium hydrosilicates.

SSC can be applied as binders of normal-weight and light-weight concrete, like sawdust concrete and expanded clay aggregate concrete [27].

\section{Conclusions}

Phosphorgypsum as alternative to natural gypsum can be applied in wide range of the construction materials. Special treatment on drying and neutralizing harmful admixtures is required. Using slaked lime (2-3\% by PG weight) is one of them most cheap ways for it.

Results of laboratory research confirms the possibility to use PG of Western Ukraine fertilizing plant as mineralizing and setting time regulator for Portland cement. It can also serve as sulphate activator for lowclinker blast furnace slag cement and supersulphated cement.

To reduce water consumption of PG superplasticizer with steric effect are applied. There have been determined the optimal content of SP. For PG binder, the water consumption can be reduced at 30 to $40 \%$, whereas compressive strength increases by 2 to 2.5 times.

The durability aspects of PG-based materials require further research.

\section{References}

1. N. Lushnikova and L. Dvorkin. The sustainability of lightweight aggregates manufactured from clay wastes for reducing the carbon footprint of structural and foundation concrete. In book: Sustainability of Construction Materials. Ed. by. J. Khatib. Cambridge: Woodhead Publishing, 643-681(2016).

2. H.Tayibi, M.Choura, F.A. López, F.J. Alguacil, and A.L. Delgado. Environmental impact and management of phosphogypsum (Review). Journal of
Environmental Management 90(8):2377-86 May (2009).

3. Mineral commodity summaries: U.S. Geological Survey, 196 p. (2015). Available at: http://minerals.usgs.gov/minerals/pubs $/ \mathrm{mcs} / 2015 / \mathrm{mcs}$ 2015.pdf

4. Phosphogypsum. Introduction. Proceedings of International Symposium on Phosphorgypsum. Utilization and/or Disposal of Phosphogypsum. Potential Barriers to Utilization. Ed. by David P. Borris and Patricia W. Boody Bartow, Florida. Reprinted, p III-VI (19870.

5. L.Y. Dvorkin, A.V. Myronenko, and T.O. PolishchukGerasimchuk, New technologies of phosphogypsum binder made of dump phosphogypsum./ Resourses saving materials, elements, structures and buildings, 16 (1), 27-34 (2008) (In Ukrainian).

6. A.P. Kouloheris. Chemical nature of hosphorgypsum as produced by various wet processes phosphoric acid processes./ Phosphogypsum. Proceedings of International Symposium on Phosphorgypsum. Utilization and/or Disposal of Phosphogypsum. Potential Barriers to Utilization. Ed. by David P. Borris and Patricia W. Boody Bartow, Florida. Reprinted, p.734 (1987)

7. S.K. Sahu, P.Y. Ajmal, R.C. Bhangare, M. Tiwari, G.G. Pandit Natural radioactivity assessment of a phosphate fertilizer plant area. Journal of Radiation Research and Applied Sciences 7, 123-128 (2014).

8. G.S. Bandgar, M.B. Kumthekar, A.B. Landage, A Review of Effective Utilization of Waste Phosphogypsum as a Building Material/ International Journal of Engineering Research. Jan, No.5, Issue Special 1. pp.: 277-280. Doi: 10.17950/ijer/v5is1/065 (2016).

9. E. Prandi, Use and valorization of phosphogypsum in road construction and civil engineering/ Phosphogypsum. Proceedings of International Symposium on Phosphorgypsum. Utilization and/or Disposal of Phosphogypsum. Potential Barriers to Utilization. Ed. by David P. Borris and Patricia W. Boody Bartow, Florida. Reprinted p. 269-278 (1987).

10. P. Pichat and R. Shinn Developments performed by A.P.C. - CdF Chimie in the field of phosphogypsum/ Phosphogypsum. Proceedings of International Symposium on Phosphorgypsum. Utilization and/or Disposal of Phosphogypsum. Potential Barriers to Utilization. Ed. by David P. Borris and Patricia W. Boody Bartow, Florida. Reprinted p 269-278 (1987).

11.S.S. Bhadauria, Utilisation of phosphogypsum in cement mortar and concrete. Rajiv Gandhi Proudyogiki Vishwavidyalya, Bhopal (M. P.) India Rajesh B. Thakare, JSPM's B. N. College of Engineering, Pusad (M. S.), India, 9 p. 31st Conference on our world in concrete and structures: 16 - 17 August, Singapore (2006).

12. L. Dvorkin, A. Myronenko, O. Dvorkin, N. Lushnikova Effect of Low-Alumina Blast Furnace Slags and Phosphogypsum Dihydrate on Properties of Supersulfated Cements. Journal "Scientific IsraelTechnological Advantages", Vol.15, \# 2, 16-29(2013). 
13. L.Y. Dvorkin, V.L Shestakov, A.A Ishchuk. Complex use of phosphogypsum I ncement production/ Resourses saving materials, elements, structures and buildings. Ed. by Y.M. Babych. - Rivne:, Issue 16 . Vol 1, pp. 35-40 (2008) (In Russian).

14. DSTU B V 2.7-3-93. Building materials. Synthetic gypsum made phosphogypsum. Technical conditions. (In Ukrainian).

15. ASTM C191 - 13. Standard Test Methods for Time of Setting of Hydraulic Cement by Vicat Needle.

16. ASTM C187 - 16. Standard Test Method for Amount of Water Required for Normal Consistency of Hydraulic Cement Paste

17. ASTM C348 - 14 Standard Test Method for Flexural Strength of Hydraulic-Cement Mortars

18. L. Dvorkin, N. Lushnikova, M. Sonebi, J. Khatib Properties of modified phosphogypsum binder./ 2nd International Conference on Bio-based Building Materials \& 1st Conference on ECOlogical valorisation of GRAnular and FIbrous materials. June 21th - 23th. Clermont-Ferrand, France (2017) [accepted to publication].

19. L. Kacimi, A. Simon-Masseron, A. Ghomari, Z. Derriche, Reduction of clinkerization temperature by using phosphogypsum. J. Haz. Mat. B137, 129-137 (2006). http://dx.doi.org/10.1016/j.jhazmat.2005.12.053.

20. L. Kacimi, A. Simon-Masseron, A. Ghomari, Z. Derriche, Influence of $\mathrm{NaF}, \mathrm{KF}$ and $\mathrm{CaF} 2$ addition on the clinker burning temperature and its properties. $\mathrm{C}$. R. Chimie. 9, 154-163 (2006). http://dx.doi.org/10.1016/j.crci.2005.10.001

21. L.Y. Dvorkin, O.L. Dvorkin, Y.A. Stepasiuk, Ways of activization of hardening low-clinker blast furnace slag/ Drypack mortars (Stroitel'nyie Smesi). Moscow,. Issue 3. - pp. 35-39 (2015). (In Russian)

22. L.Y. Dvorkin, N.V. Lushnikova, Properties of Gypsum Binders Modified with Complex Admixtures. Ibausil, Internationale Baustofftagung, Tagunsbericht Weimar, Institut für Baustoffkunde, Band I: 1-0701 - 1-0707 (2009).

23. M. Marschetzky, H.-B. Fischer, H.-M. Ludwig, Superplasticizers in the calcium sulfate system plasticizing action and influence on hydration. ZKG International. January 66(2):42-54 (2013).

24. J. Peng, J. Qu, J. Zhang, M. Chen, T. Wan, Adsorption characteristics of water reducing agents on gypsum surface and its effect on the rheology of gypsum plaster. Cement and Concrete Research. 35(3): 527531 (2005).

25. L.Y. Dvorkin, A.V. Myronenko, T.O. PolishchukGerasimchuk, Drypack gypsum and phosphogypsum mixes with effective modifiers. / Building mateirals and products (Stroitel'nyie materialy i izdelia)., Issue 6, pp. 20-23 (2012). - Available at: http://nbuv.gov.ua/UJRN/smii 2012 $6 \quad 10$ (In Ukrainian).

26. M.C.G Juenger, et al. Advances in Alternative Cementitious Binders. Cement and Concrete Research, 41 (12), 1232-1243 (2011).

27. L. Dvorkin, N. Lushnikova, M. Sonebi, J.M. Khatib, Light weight claydite and sawdust concrete based on supersulphated cement. / 2nd International Conference on Bio-based Building Materials \& 1st Conference on ECOlogical valorisation of GRAnular and FIbrous materials. June 21th - 23th. Clermont-Ferrand, France (2017) [accepted to be publication]. 